BUDGETING : Journal of Business, Management and Accounting

Volume 2, Nomor 1, Desember 2020

e-ISSN: 2715-2480

p-ISSN: 2715-1913

DOI : https://doi.org/10.31539/budgeting.v2i1.1740

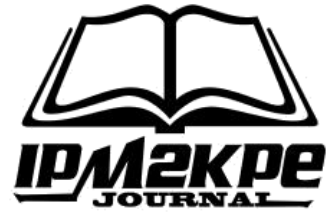

\title{
EKSISTENSI PENCATATAN KEUANGAN \\ BERDASARKAN SAK EMKM PADA UMKM DENGAN APLIKASI MICROSOFT EXCEL
}

\author{
Erlin Amma Wahyuni E. L. ${ }^{1}$, Diyah Probowulan ${ }^{2}$, Retno Murwanti ${ }^{3}$ \\ Universitas Muhammadiyah Jember ${ }^{1,2,3}$ \\ erlin2020@gmail.com ${ }^{1}$
}

\begin{abstract}
ABSTRAK
Tujuan penelitian ini adalah untuk menerapkan metode pencatatan keuangan yang sesuai dengan Standar Akuntansi Keuangan Mikro, Kecil dan Menengah (SAK EMKM) pada CV. Teras Jaya dengan menggunakan Microsoft Excel. Penelitian ini menggunakan jenis penelitian dengan pendekatan deskriptif kualitatif dengan metode studi kasus. Data yang diperoleh dan digunakan dalam penelitian ini adalah jenis data primer dan sekunder. Metode pengumpulan data melalui wawancara, observasi dan dokumentasi. Hasil penelitian menunjukkan bahwa rekonstruksi laporan keuangan CV. Teras Jaya yang disesuaikan dengan SAK EMKM dilakukan pada laporan posisi keuangan, laporan laba rugi dan catatan atas laporan keuangan. Simpulan, laporan keuangan yang disusun oleh CV. Teras Jaya masih sangat sederhana. Rekostruksi penyusunan dan penyajian laporan keuangan berdasarkan SAK EMKM dimulai dari mengumpulkan data transaksi, menganalisis data transaksi, mencatat transaksi dalam jurnal umum, buku besar, neraca saldo dan neraca lajur. Kemudian dilanjutkan dengan pembuatan laporan keuangan yang dimulai dari laporan posisi keuangan, laporan laba/rugi dan catatan atas laporan keuangan.
\end{abstract}

Kata Kunci: Laporan Keuangan, SAK EMKM, UMKM

\begin{abstract}
The purpose of this research is to apply financial recording methods that are in accordance with the Accounting Standards for Micro, Small and Medium Enterprises (SAK EMKM) at CV. Teras Jaya using Microsoft Excel. This research uses a type of research with a qualitative descriptive approach with a case study method. The data obtained and used in this study are primary and secondary data. Methods of data collection through interviews, observation and documentation. The results showed that the reconstruction of the financial statements of $C V$. Teras Jaya, which is adjusted to SAK EMKM, is carried out in the statement of financial position, income statement and notes to financial statements. In conclusion, the financial statements prepared by $C V$. Teras Jaya is still very simple. Reconstruction of the preparation and presentation of financial statements based on SAK EMKM starts from collecting transaction data, analyzing transaction data, recording transactions in general journals, ledgers, trial balances and work sheets. Then proceed with the preparation of financial reports, starting from the statement of financial position, profit / loss statement and notes to financial statements.
\end{abstract}

Keywords: Financial Statements, SAK EMKM, UMKM 


\section{PENDAHULUAN}

Usaha Mikro, Kecil dan Menengah (UMKM) merupakan salah satu penggerak perekonomian bangsa karena dapat mendorong pertumbuhan ekonomi untuk masyarakat menengah ke bawah. UMKM merupakan salah satu usaha yang banyak didirikan oleh masyarakat terutama dari golongan menengah ke bawah. Selain mengeluarkan modal yang tidak besar, usaha ini telah membuka lapangan kerja baru bagi masyarakat Indonesia sehingga dapat menyerap tenaga kerja Indonesia. Penyerapan tenaga kerja baru oleh UMKM akan berdampak secara signifikan dalam menurunkan tingkat pengangguran masyarakat Indonesia.

Seiring dengan kemajuan dunia usaha, ternyata masih banyak UMKM yang belum menggunakan sistem akuntansi yang benar serta standar akuntansi yang berlaku. Kebanyakan dari pelaku usaha tersebut masih menggunakan pencatatan laporan keuangan yang masih sederhana. Mayoritas pengusaha UMKM tidak mampu memberikan informasi akuntansi terkait kondisi usahanya sehingga terjadi kesulitan dalam mengukur kinerja perusahaan. Akan tetapi, keberadaan laporan keuangan sangat bermanfaat dalam membantu UMKM untuk mengambil keputusan dalam pengelolaan usaha.

Laporan keuangan berfungsi sebagai alat untuk menganalisis kinerja keuangan yang dapat memberikan informasi tentang posisi keuangan, kinerja dan arus kas. Sehingga dapat dijadikan sebagai dasar pembuatan keputusan ekonomi (Putra, 2012). Penelitian ini akan membahas mengenai eksistensi pencatatan laporan keuangan berdasarkan SAK EMKM yang sudah berlaku mulai 1 Januari 2018. Dengan tujuan untuk merancang sistem akuntansi sederhana yang dapat membentu dan mempermudah pemilik usaha dalam membuat laporan keuangannya berdasarkan standar yang berlaku saat ini. Dengan laporan keuangan diharapkan para pemilik UMKM dapat mengevaluasi usahanya dan menggunakan informasi laporan keuangan sebagai dasar pengambilan keputusan.

Berdasarkan Undang-Undang Republik Indonesia No. 20 (2008), CV. Teras Jaya termasuk salah satu perusahaan kecil menengah yang berada di Kabupaten Jember. Perusahaan ini bergerak pada bidang perdagangan, seperti penjualan material bangunan, barang konstruksi dari semen seperti gorong-gorong, paving, batako dan kusen beton. CV. Teras Jaya sudah lama menjalankan kegiatan operasionalnya sejak tahun 1999. 
Tetapi karena keterbatasan pengelolaan keuangan dan sumber daya manusia yang kurang memadai dalam penyusunan laporan keuangan menyebabkan perusahaan mengelola usahanya tidak sesuai SAK EMKM.

Laporan keuangan yang dicatat oleh pemilik perusahaan hanyalah pemasukan dan pengeluarannya saja. Padahal setiap perusahan harus memiliki laporan keuangan yang memadai dan disajikan sesuai SAK EMKM, sehingga dapat mempermudah penyusunan laporan keuangannya. Berdasarkan hal tersebut, peneliti tertarik untuk melakukan penelitian studi kasus pada CV. Teras Jaya Kecamatan Wuluhan Kabupaten Jember mengenai eksistensi pencatatan keuangan berdasarkan SAK EMKM menggunakan aplikasi microsoft excel.

\section{KAJIAN TEORI}

\section{Usaha Mikro, Kecil dan Menengah (UMKM)}

Berdasarkan Undang-Undang Republik Indonesia No. 20 (2008), UMKM merupakan usaha ekonomi produktif milik orang perseorangan dan/atau badan usaha perorangan yang bukan merupakan anak perusahaan atau bukan cabang perusahaan yang dimiliki, dikuasai atau menjadi bagian baik langsung maupun tidak langsung dari usaha menengah atau usaha yang memenuhi kriteria usaha kecil.

UMKM adalah kegiatan usaha yang mampu memperluas lapangan kerja dan memberikan pelayanan ekonomi secara luas kepada masyarakat dan dapat berperan dalam proses pemerataan dan peningkatan pendapatan masyarakat, mendorong pertumbuhan ekonomi dan berperan dalam mewujudkan stabilitas nasional. Selain itu UMKM termasuk salah satu pilar utama ekonomi nasional yang harus memperoleh kesempatan utama, dukungan, perlindungan dan pengembangan seluas-luasnya sebagai wujud keberpihakan yang tegas kepada kelompok usaha ekonomi rakyat tanpa mengabaikan peranan Usaha Besar dan Badan Usaha Milik Negara (Tunggal, 2008).

Kriteria UMKM berdasarkan Undang-Undang Republik Indonesia No. 20 (2008) adalah sebagai berikut: 1) kriteria usaha mikro memiliki kekayaan bersih paling banyak Rp50.000.000,00 (lima puluh juta rupiah) tidak termasuk tanah dan bangunan tempat usaha atau memiliki hasil penjualan tahunan paling banyak Rp300.000.000,00 (tiga ratus juta rupiah); 2) kriteria usaha kecil memiliki kekayaan bersih lebih dari Rp50.000.000,00 (lima puluh juta rupiah) dan paling banyak Rp500.000.000,00 (lima 
ratus juta rupiah), tidak termasuk tanah dan bangunan tempat usaha atau memiliki hasil penjualan tahunan lebih dari Rp300.000.000,00 (tiga ratus juta rupiah) sampai dengan paling banyak Rp2.500.000.000,00 (dua milyar lima ratus juta rupiah).

Selanjutnya, 3) kriteria usaha menengah memiliki kekayaan bersih lebih dari Rp500.000.000,00 (lima ratus juta rupiah) dan paling banyak Rp10.000.000.000,00 (sepuluh milyar rupiah), tidak termasuk tanah dan bangunan tempat usaha atau memiliki hasil penjualan tahunan lebih dari Rp2.500.000.000,00 (dua milyar lima ratus juta rupiah) sampai dengan paling banyak Rp50.000.000.000,00 (lima puluh milyar rupiah); 4) kriteria sebagaimana dimaksud pada ayat (1) huruf a, dan ayat (2) huruf a, serta ayat (3) huruf a, nilai nominalnya dapat diubah sesuai dengan perkembangan perekonomian yang diatur dengan Peraturan Presiden.

Berdasarkan data Badan Pusat Statistik, jumlah tenaga kerja UMKM adalah kurang dari 100 orang, dengan rincian kategori sebagai berikut: a) usaha rumah tangga atau mikro terdiri dari 1-4 tenaga kerja; b) usaha kecil terdiri dari 5-19 tenaga kerja; c) usaha menengah terdiri dari 20-99 tenaga kerja; d) usaha besar memiliki tenaga kerja sebanyak 100 tenaga kerja atau lebih (Ningtyas, 2017).

\section{Fungsi dan Peran Usaha Mikro, Kecil dan Menengah (UMKM)}

Menurut Suryana (2001) fungsi dan peran UMKM sangat besar dalam kegiatan ekonomi masyarakat. Fungsi dan peran itu meliputi penyediaan barang dan jasa, penyerapan tenaga kerja, pemerataan pendapatan, sebagai nilai tambah bagi produk daerah dan peningkatan taraf hidup masyarakat.

\section{Laporan Keuangan}

Laporan keuangan merupakan catatan informasi suatu perusahaan pada periode akuntansi yang menggambarkan kinerja perusahaan tersebut. Laporan keuangan berguna bagi bankir, kreditor, pemilik dan pihak-pihak yang berkepentingan dalam menganalisis serta menginterprestasikan kinerja keuangan dan kondisi perusahaan (Ikatan Akuntansi Indonesia, 2016).

Laporan keuangan adalah hasil dari proses akuntansi yang menyediakan informasi keuangan suatu perusahaan yang bermanfaat bagi pihak-pihak yang berkepentingan dalam pengambilan keputusan ekonomi. Laporan Keuangan terdiri dari 
lima macam, yaitu laporan laba/rugi, neraca, perubahan modal, arus kas serta catatan atas laporan keuangan (Isnawan, 2012).

\section{Tujuan Laporan Keuangan}

Menurut Ikatan Akuntansi Indonesia (2012), beberapa tujuan laporan keuangan sebagai berikut: 1) menyediaan informasi yang mengangkat posisi keuangan, kinerja, serta perubahan posisi keuangan suatu entitas yang bermanfaat bagi sejumlah besar pengguna dalam pengambilan keputusan ekonomi; 2) laporan keuangan yang disusun bertujuan untuk memenuhi kebutuhan bersama bagi para penggunanya yang secara umum menggambarkan pengaruh keuangan dari kejadian dimasa lalu; 3) laporan keuangan menunjukkan apa yang telah dilakukan manajemen (stewardship) atas pertanggungjawaban manajemen.

\section{Jenis-Jenis Laporan Keuangan}

Menurut Ikatan Akuntansi Indonesia (2016), laporan keuangan terdiri dari: a) laporan posisi keuangan, laporan ini menyajikan informasi tentang aset, liabilitas dan ekuitas entitas pada akhir periode pelaporan. Pos-pos yang mencakup diantaranya kas dan setara kas, piutang, persediaan, aset tetap, utang usaha, utang bank dan ekuitas. SAK EMKM tidak menentukan format atau urutan terhadap pos-pos yang disajikan. Meskipun demikian, entitas dapat menyajikan pos-pos aset berdasarkan urutan likuiditas dan pos-pos liabilitas berdasarkan urutan jatuh tempo.

Selanjutnya, b) laporan laba rugi, laporan ini memasukkan semua penghasilan dan beban yang diakui dalam suatu periode, kecuali SAK EMKM yang mensyaratkan lain. Pos-Pos yang mencakup diantaranya pendapatan beban keuangan dan beban pajak; c) catatan atas laporan keuangan, catatan ini disajikan secara sistematis sepanjang hal tersebut praktis. Setiap pos dalam laporan keuangan merujuk silang ke informasi terkait dalam catatan atas laporan keuangan. Pos-pos mencakup suatu pernyatan bahwa laporan keuangan telah disusun sesuai dengan SAK EMKM, ikhtisar kebijakan akuntansi dan informasi tambahan dan rincian pos tertentu yang menjelaskan transaksi penting dan material sehingga bermanfaat bagi pengguna untuk memahami laporan keuangan. 


\section{METODE PENELITIAN}

Penelitian ini menggunakan jenis penelitian dengan pendekatan deskriptif kualitatif dengan metode studi kasus. Penelitian dengan pendekatan deskriptif kualitatif merupakan metode yang dapat memberikan gambaran yang berkaitan dengan data sesuai dengan fakta yang didapat oleh peneliti (Husein, 2014). Objek penelitian yang diambil peneliti adalah UMKM yang ada di Kecamatan Wuluhan Kabupaten Jember. Daerah penelitian adalah tempat yang dilaksanakannya penelitian. Daerah penelitian ini ditetapkan di CV. Teras Jaya yang beralamatkan di Dusun Gawok Desa Dukuh Dempok Kecamatan Wuluhan Kabupaten Jember.

Data yang diperoleh dan digunakan dalam penelitian ini adalah jenis data primer dan sekunder. Untuk mendukung penelitian ini, peneliti membutuhkan data yang relevan, maka pada saat pengumpulan data peneliti menerapkan teknik sebagai berikut: a) wawancara, merupakan salah satu teknik pengumpulan data baik secara langsung berhadapan dengan yang diwawancarai maupun tidak langsung seperti memberikan daftar pertanyaan untuk dijawab pada lain kesempatan (Husein, 2014). Guna untuk menunjang penelitian maka peneliti melakukan wawancara atau tanya jawab secara langsung dengan pemilik UMKM CV. Teras Jaya dan pihak berkepentingan lainnya untuk mendapatkan data yang diperlukan.

Selanjutnya, b) observasi, menurut Creswell (2014) observasi adalah metode pengumpulan data dengan peneliti langsung turun ke lapangan untuk mengamati perilaku dan aktivitas individu dilokasi penelitian. Teknik pengumpulan data melalui observasi sangat mendukung peneliti dalam menyelesaikan penelitian ini dengan mengetahui secara langsung kondisi di lokasi penelitian; c) dokumentasi, yaitu metode pencarian dan pengumpulan data mengenai catatan, buku-buku, majalah, dokumen dan sebagainya (Sugiyono, 2014). Dalam hal ini peneliti melakukan pengumpulan dokumentasi yang didapat dari CV. Teras Jaya berupa laporan keuangan, catatan keuangan, profil perusahaan dan sebagainya.

Langkah-langkah analisis penelitian ini adalah: 1) mendeskripsikan kondisi pencatatan keuangan pada CV. Teras Jaya yang telah dilakukan selama ini baik sebelum, saat dan setelah terjadinya proses ekonomi; 2) mengidentifikasi aktivitas keuangan CV. Teras Jaya. Aktifitas keuangannya antara lain dari mulai proses pembelian bahan baku, proses penjualan sampai perhitungan laba dan gaji pegawai serta 
transaksi lain yang menunjang CV. Teras Jaya; 3) rekonstruksi laporan keuangan CV. Teras jaya meliputi kas dan setara kas, piutang, persediaan, aset tetap, ekuitas, pendapatan, beban keuangan dan beban pajak; 4) menyusun laporan keuangan CV. Teras Jaya berdasarkan Standar Akuntansi Keuangan Entitas Mikro, Kecil dan Menengah (SAK EMKM). Laporan lengkap seperti laporan posisi keuangan, laporan laba rugi dan catatan atas laporan keuangan.

\section{HASIL PENELITIAN}

\section{Sejarah CV. Teras Jaya}

CV. Teras Jaya merupakan usaha dagang milik perseorangan yang didirikan oleh Bapak Ismail Marzuki pada tahun 1999 yang bergerak dalam bidang perdagangan material bangunan, barang konstruksi dari semen (gorong-gorong, paving, kusen beton). Usaha ini termasuk dalam kategori Usaha Mikro, Kecil dan Menengah (UMKM). Perusahaan ini beralamat di Dusun Gawok Desa Dukuh Dempok Kecamatan Wuluhan Kabupaten Jember.

Modal awal CV. Teras Jaya sebesar Rp1.000.000,00 yang didapat dari hutang Bank Kredit Desa Dukuh Dempok Wuluhan. Modal tersebut dikembangkan untuk usaha gorong-gorong (cempolong) yang biasa digunakan untuk sumur dan septic tank (WC). Usaha ini hanya bertahan pada musim kemarau saja karena pada musim penghujan, usaha tersebut tidak bisa melakukan proses penjemuran. Tahun 2000 modal berkembang menjadi Rp2.500.000,00 dan menambah produk yaitu tiang teras. Untuk cetakan tiang teras membuat sendiri dari semen dan memliki 3 unit cetakan dan hasil penjualan dalam 1 tahun itu menjadi Rp7.500.000,00. Kemudian pada tahun 2001, CV. Teras Jaya menambah produksi batako. Modal untuk membuat batako tidak terlalu besar pada cetakan, tetapi modal paling besar dikeluarkan pada bahan baku pasir dan semen yang sangat banyak dibutuhkan. Laba yang didapatkan dari batako ini hanya sedikit, tetapi pelanggannya sudah mulai banyak.

Tahun 2012 merupakan tahun yang sangat menentukan bagi usaha CV. Teras Jaya ini karena pada tahun ini mendapatkan inisiatif baru untuk membuat kusen beton yang belum ada di Desa Dukuh Dempok. Teknologi untuk membuat kusen beton ini didapatkan dari Blitar. Biasanya pada saat musim kemarau proses pembuatan dipercepat. Kusen beton ini mendapatkan antusias yang sangat luar biasa dari para 
pelanggan karena hanya perusahaan ini yang memproduksi produk tersebut di Desa Dukuh Dempok. Modal perusahaan berkembang pesat dari hasil penjualan kusen beton, sehingga modal bisa dikembangkan ke produk yang lain seperti lisplang, membuat batako dan paving dengan mesin.

\section{Struktur Organisasi CV. Teras Jaya}

Struktur organisasi pada CV. Teras Jaya sangat sederhana. Kegiatan yang terjadi di CV. Teras Jaya dikelola langsung oleh pemilik perusahan yaitu Bapak Ismail Marzuki yang merangkap sebagai manajer dan pengelola keuangan dan beberapa karyawan yang bekerja.

Tugas masing-masing bagian dalam struktur organisasi CV. Teras Jaya adalah sebagai berikut: 1) pemilik CV. Teras Jaya, bertugas memberikan modal untuk seluruh kebutuhan usahanya, memantau dan mempertahankan kelangsungan usaha, mengawasi kinerja karyawan, dan melakukan pemesanan dan pembelian bahan baku; 2) manajer, bertanggungjawab dalam membuat rencana, memimpin untuk mencapai sasaran tertentu dan merangkap sebagai pengelola dan pencatat keuangan; 3) karyawan, bertugas melakukan pekerjaan yang ditugaskan oleh manajer. Karyawan CV. Teras Jaya bertugas di bagian produksi, sopir truk, pengiriman dan toko.

Bagian produksi, bertugas mengatur kegiatan-kegiatan yang diperlukan bagi terselenggaranya proses produksi. Terdapat 7 macam jenis produksi yaitu: 1) cetak batako, merupakan jenis material bangunan yang dibuat dari bahan campuran pasir atau abu batu dan semen yang biasa digunakan untuk dinding rumah, dinding pagar dan lainlain; 2) cetak paving, yaitu jenis material bangunan yang dibuat dari bahan campuran pasir dan semen yang biasa digunakan sebagai salah satu alternatif penutup atau pengerasan permukaan tanah; 3) cetak tiang, merupakan jenis material bangunan yang dibuat dari bahan campuran pasir dan semen yang biasa digunakan sebagai salah satu alternatif untuk menyokong atau menyangga atap rumah.

Selanjutnya, 4) cetak loster, yaitu jenis material bangunan yang dibuat dari bahan campuran pasir dan semen yang yang mempunyai fungsi sebagai lubang utilitas untuk sirkulasi udara (angin) dan pencahayan di siang hari pada sebuah ruang dalam satu bangunan; 5) cetak lisplang, merupakan jenis material bangunan yang dibuat dari bahan campuran pasir dan semen yang berfungsi menutup bagian atas bangunan 
sehingga tampak rapi ketika dilihat dari bawah; 6) cetak kusen beton, yaitu jenis material bangunan yang dibuat dari bahan campuran pasir dan semen yang biasa digunakan sebagai salah satu alternatif pengganti kusen kayu, sehingga lebih kuat dan kokoh; 7) cetak gorong-gorong, merupakan jenis material bangunan yang dibuat dari bahan campuran pasir dan semen yang biasa digunakan sebagai salah satu alternatif saluran air dalam tanah, sumur dan septic tank (sumur wc).

Adapun tugas di bagian sopir yaitu mengambil material di penambang. Bagian pengiriman bertugas mengirim barang dagang kepada konsumen dan bertanggung jawab atas barang dagang tersebut. Kemudian bagian toko bertugas melayani pembeli dan selalu siap untuk membantu mencarikan barang yang dibutuhkan pembeli.

Berikut ini merupakan skema rekonstruksi struktur organisasi CV. Teras Jaya:

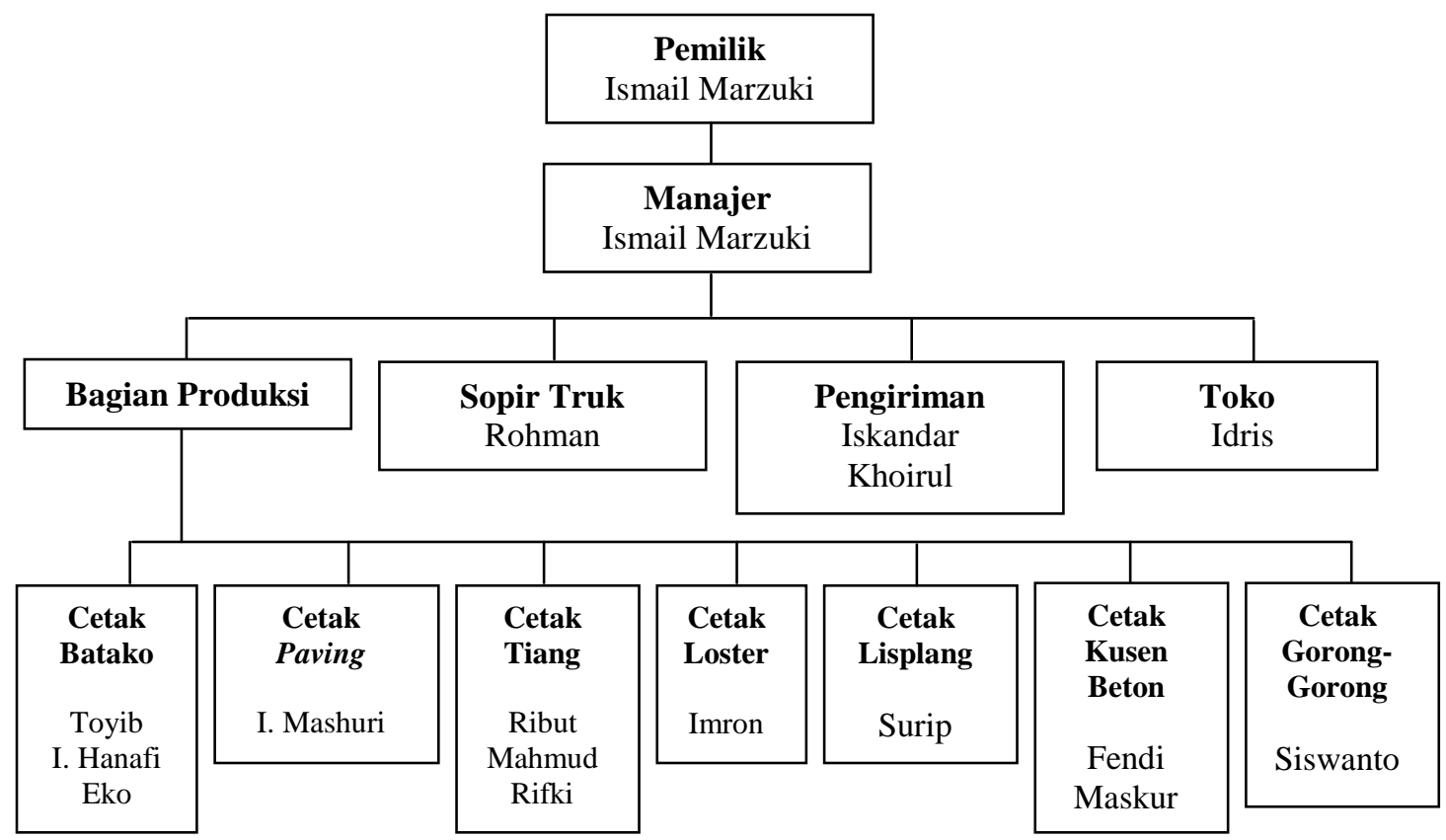

Gambar 1.

Skema Rekonstruksi Struktur Organisasi CV. Teras Jaya

\section{Laporan Keuangan CV. Teras Jaya}

Saat ini CV. Teras Jaya sudah beroperasi selama 20 tahun. Namun banyak permasalahan yang terjadi dalam kurun waktu tersebut. Salah satunya yaitu laporan keuangan pada CV. Teras Jaya yang masih sangat sederhana. Laporan Keuangan pada $\mathrm{CV}$. Teras Jaya disusun oleh pemilik yang merangkap sebagai manajer dan karyawan yang bertugas melakukan pengelolaan dan pencatatan keuangan. 
Laporan Keuangan yang dibuat CV. Teras Jaya antara lain: 1) laporan pengeluaran belanja bahan baku, yaitu catatan pengeluaran yang dibuat setelah perusahaan melakukan transaksi pembelian bahan baku; 2) laporan penjualan hasil produksi, yaitu catatan penerimaan penjualan yang dibuat untuk mencatat seluruh penerimaan uang masuk dari hasil penjualan dan dibuat untuk mencatat hasil penjualan selama periode tertentu; 3) prive, yaitu catatan pengeluaran yang dibuat untuk pengambilan modal yang digunakan untuk kepentingan pribadi; 4) laporan gaji karyawan, yaitu daftar gaji karyawan dibuat setiap hari karena sistem pembayarannya ada yang dibayarkan setiap hari dan ada yang dibayarkan setiap satu minggu sekali; 5) laporan beban perusahaan, yaitu laporan yang dibuat untuk mengetahui banyaknya beban yang dikeluarkan selama periode tertentu.

\section{Aktivitas CV. Teras Jaya}

CV. Teras Jaya memiliki beberapa aktivitas diantaranya yaitu: 1) aktivitas pemasaran, produk dipasarkan di Kecamatan Wuluhan, Ambulu, Balung, Rambipuji dan sampai ke Jenggawah. CV. Teras Jaya tidak memiliki strategi pemasaran yang khusus dalam memasarkan produknya; 2) aktivitas pembelian bahan baku, pembelian bahan baku tergantung banyak atau tidaknya pemesanan. Jika pesanan banyak, maka pembelian bahan baku bisa dilakukan setiap hari.

Selanjutnya, 3) aktivitas sumber daya manusia, CV. Teras Jaya memperkerjakan karyawan sebanyak 16 orang (3 karyawan cetak batako, 1 karyawan cetak paving, 3 karyawan cetak tiang, 1 karyawan cetak loster, 1 karyawan cetak lisplang, 2 karyawan cetak kusen beton, 1 karyawan cetak gorong-gorong, 1 karyawan bagian sopir, 2 karyawan bagian pengiriman dan 1 karyawan bagian toko.

Sistem gaji pada CV. Teras Jaya terdiri dari dua sistem yaitu sistem borongan dan sistem harian. Ada 6 orang karyawan yang digaji menggunakan sistem borongan dan 10 orang dengan sistem harian. 


\section{Rekonstruksi Laporan Keuangan CV. Teras Jaya Berdasarkan SAK EMKM}

Penerapan SAK EMKM pada laporan keuangan CV. Teras Jaya dilakukan untuk mengetahui langkah-langkah yang harus dilaksanakan dalam pengakuan dan pengukuran unsur laporan keuangan. Langkah selanjutnya adalah membuat jurnal umum yang dimasukkan pada Microsoft Excel, buku besar, neraca saldo, neraca lajur dan laporan keuangan. SAK EMKM hanya terdiri dari 3 laporan keuangan yaitu laporan posisi keuangan, laporan laba rugi dan catatan atas laporan keuangan.

\section{Laporan Posisi Keuangan}

Laporan posisi keuangan menyajikan aset, liabilitas dan ekuitas suatu entitas pada akhir periode pelaporan. Laporan posisi keuangan dikatakan seimbang apabila jumlah aset sama dengan jumlah liabilitas dan ekuitas. Berdasarkan hasil analisis, CV. Teras Jaya belum menerapkan laporan posisi keuangan dalam laporan keuangannya.

Tabel 1.

Laporan Posisi Keuangan CV. Teras Jaya

Per 31 Desember 2018 dengan SAK EMKM

\begin{tabular}{crcc}
\hline \multicolumn{2}{c}{ Aktiva } & \multicolumn{2}{c}{ Passiva } \\
\hline \multicolumn{2}{c}{ Aset Lancar (Rp) } & Hutang & - \\
\hline Kas dan Setara Kas & $1.525 .147 .000,00$ & & \\
Persediaan & $450.000 .000,00$ & & \\
Bahan Baku & $1.558 .678 .000,00$ & Ekuitas (Rp) \\
\hline Jumlah Aset Lancar & $3.533 .825 .000,00$ & $1.000 .000 .000,00$ \\
\hline Aset Tetap (Rp) & $100.000 .000,00$ & $-5.500 .000,00$ \\
Peralatan & $-37.500 .000,00$ & Prive & $3.358 .025 .000,00$ \\
Akm. Penyusutan & $420.000 .000,00$ & Saldo Laba \\
Peralatan & $600.000 .000,00$ & & \\
Tanah & $-399.000 .000,00$ & & \\
Gedung & $260.000 .000,00$ & & \\
Akm. Penyusutan & $-124.800 .000,00$ & & \\
Gedung & $818.700 .000,00$ & & \\
Kendaraan & $4.352 .525 .000,00$ & Jumlah Kewajiban dan & \\
Akm. Penyusutan & & Ekuitas \\
Kendaraan & &
\end{tabular}

\section{Laporan Laba Rugi}

Laporan laba rugi menyajikan laporan pendapatan dan beban selama periode tertentu. Berikut ini adalah penyajian laporan posisi laba rugi CV. Teras Jaya per 31 Desember 2018 yang sesuai dengan SAK EMKM: 
Tabel 2.

Laporan Laba/Rugi CV. Teras Jaya

Per 31 Desember 2018

\begin{tabular}{lrr}
\hline Beban & Jumlah (Rp) \\
\hline Beban Gaji & $249.888 .000,00$ & \\
Beban Konsumsi & $17.210 .000,00$ & \\
Beban Listrik & $5.707 .000,00$ & \\
Beban Pemeliharaan Kendaraan & $55.338 .000,00$ & \\
Beban Pemeliharaan Peralatan & $2.480 .000,00$ & \\
Beban Bahan Bakar & $6.530 .000,00$ & \\
Beban Sewa Gergaji & $885.000,00$ & \\
BebanTunjangan Hari Raya & $6.407 .000,00$ & $-435.569 .000,00$ \\
Beban Pajak Kendaraan & $2.160 .000,00$ & $3.793 .594 .000,00$ \\
Beban Penyusutan Gedung & $28.500 .000,00$ & $3.358 .025 .000,00$ \\
Beban Pajak Kendaraan & $41.600 .000,00$ & \\
Beban Pajak Bumi Bangunan & $114.000,00$ & \\
Beban Penyusutan Peralatan & $18.750 .000,00$ & \\
\hline Jumlah Beban & & \\
\hline Pendapatan & & \\
\hline Laba Bersih & & \\
\hline
\end{tabular}

(Sumber: Data Diolah)

\section{Catatan Atas Laporan Keuangan}

Catatan atas laporan keuangan berisi informasi sebagai tambahan informasi dan rincian yang disajikan bergantung pada jenis kegiatan usaha yang dilakukan entitas. Berikut ini adalah penyajian catatan atas laporan keuangan CV. Teras Jaya:

\section{UMUM}

CV. Teras Jaya didirikan di Jember, dan merupakan Usaha Dagang yang telah memiliki Surat Izin Usaha Perdagangan (SIUP) dari Dinas Perindustrian Perdagangan dan Energi Sumber Daya Mineral Kabupaten Jember. Berdasarkan Undang-Undang No. 20 Tahun 2008 CV. Teras Jaya termasuk dalam kriteria Usaha Mikro Kecil dan Menengah (UMKM).

\section{IKHTISAR KEBIJAKAN AKUNTANSI PENTING}

a. Pernyataan Kepatuhan

Laporan keuangan disusun menggunakan Standar Akuntansi Keuangan Entitas Mikro, Kecil dan Menengah (SAK EMKM).

b. Dasar Penyusunan

Dasar penyusunan laporan keuangan adalah biaya historis dan menggunakan asumsi dasar akrual. Mata uang penyajian yang digunakan untuk penyusunan laporan keuangan adalah Rupiah.

c. Persediaan

Biaya persediaan bahan baku meliputi biaya pembelian dan biaya angkut pembelian. Biaya konversi meliputi biaya tenaga kerja langsung dan overhead. Overhead tetap dialokasikan ke biaya konversi berdasarkan kapasitas produksi normal. Overhead variabel dialokasikan pada unit produksi berdasarkan penggunaan aktual fasilitas produksi. Entitas menggunakan rumus biaya persediaan rata-rata.

d. Aset Tetap

Aset tetap dicatat sebagai biaya perolehannya jika aset tersebut dimiliki secara hukum oleh entitas. Aset tetap disusutkan menggunakan metode garis lurus tanpa nilai residu. 
e. Pengakuan Pendapatan dan Beban

Pendapatan penjualan diakui ketika tagihan diterbitkan atau pengiriman dilakukan kepada pelanggan. Beban diakui saat hal tersebut terjadi.

f. Pajak Kendaraan

(Sumber: Data Diolah)

Pajak kendaraan mengikuti ketentuan perpajakan yang berlaku di Indonesia.

Gambar 2.

Catatan Atas Laporan Keuangan CV. Teras Jaya

Per 31 Desember 2018 Sesuai SAK EMKM

\section{PEMBAHASAN}

Standar Akuntansi Keuangan memiliki kerangka konseptual yang mendasari pelaksanaan teknik-tekniknya. Kerangka konseptual mirip dengan konstitusi yaitu suatu sistem koheren yang terdiri dari tujuan dan konsep fundamental yang saling berhubungan dan menjadi landasan bagi penetapan standar yang konsisten dan penetuan sifat, fungsi serta batas-batas dari akuntansi keuangan dan laporan keuangan. Standar dan prinsip akuntansi yang digunakan di Indonesia disusun dan dikeluarkan oleh Ikatan Akuntan Indonesia (IAI). IAI sendiri merupakan suatu organisasi yang menaungi profesi akuntan di Indonesia (Uno et al., 2015).

Laporan keuangan didefinisikan sebagai laporan yang umumnya terdiri dari neraca dan perhitungan laba rugi serta perubahan ekuitas. Neraca menggambarkan jumlah aset, kewajiban dan ekuitas dari suatu perusahaan pada periode tertentu. Adapun laba rugi merupakan laporan hasil-hasil dan beban perusahaan yang telah dicapai (Munawir, 2010). Laporan keuangan dikenal sebagai catatan informasi keuangan suatu perusahaan pada suatu periode akuntansi yang dapat digunakan untuk menggambarkan kinerja perusahaan. Dengan kata lain bahwa laporan keuangan merupakan ringkasan dari suatu proses pencatatan dari transaksi-transaksi keuangan yang terjadi selama tahun buku yang bersangkutan (Baridwan, 2008)

Berdasarkan SAK EMKM, tujuan laporan keuangan yang disajikan oleh suatu entitas adalah sebagai berikut: 1) memberikan informasi keuangan yang dapat dipercaya mengenai sumber-sumber ekonomi dan kewajiban serta modal perusahaan; 2) memberikan informasi yang dapat dipercaya mengenai perubahan sumber-sumber ekonomi perusahaan yang timbul dalam aktivitas usaha demi memperoleh laba; 3) memberikan informasi keuangan yang memudahkan para pemakai laporan untuk mengestimasi potensi perusahaan dalm menghasilkan laba masa depan; 4) memberikan 
informasi keuangan yang memudahkan para pemakai laporan ketika mengestimasi potensi perusahaan dalam menghasilkan laba (Ikatan Akuntansi Indonesia, 2016).

Hasil penelitian ini menunjukkan bahwa laporan keuangan CV. Teras Jaya masih disajikan dalam bentuk yang sangat sederhana, sehingga laporan tersebut perlu direkonstruksi agar UMKM ini mampu untuk mencapai literasi keuangan dan mengoptimalkan kinerjanya khususnya dalam hal mencari sumber pendanaan. Hasil tersebut sejalan dengan temuan Uno et al., (2019) pada Rumah Karawo di Kota Gorontalo. Rumah makan tersebut juga belum menerapkan SAK EMKM dalam penyusunan laporan keuangannya karena pihak yang menjalankan usaha merasa penyusunan laporan keuangan sesuai dengan standar bukanlah hal yang penting. Padahal menurut Mubiroh \& Ruscitasari (2019) SAK EMKM ditujukan untuk UMKM secara menyeluruh agar UMKM dapat menyusun laporan keuangan yang berkualitas.

\section{SIMPULAN}

Laporan keuangan yang disusun oleh CV. Teras Jaya masih sangat sederhana. Pembukuan setiap harinya hanya berisi tentang kas masuk dan kas keluar yang terjadi pada hari itu seperti laporan penjualan, laporan gaji karyawan, laporan pembelian bahan baku dan laporan beban-beban usaha. CV. Teras Jaya belum menerapkan laporan keuangan yang sesuai dengan SAK EMKM. Penyusunan dan penyajian laporan keuangan berdasarkan SAK EMKM dimulai dari mengumpulkan data transaksi, menganalisis data transaksi, mencatat transaksi dalam jurnal umum, buku besar, neraca saldo dan neraca lajur. Selanjutnya yaitu membuat laporan keuangan yang dimulai dari laporan posisi keuangan, laba dan catatan atas laporan keuangan yang menyajikan gambaran umum perusahaan dan kepatuhan CV. Teras Jaya yang telah menyusun laporan keuangan sesuai SAK EMKM dengan menggunakan Microsoft Excel.

\section{DAFTAR PUSTAKA}

Baridwan, Z. (2008). Intermediate Accounting, Edisi Delapan, Cetakan Kedua. Yogyakarta: BPFE-Yogyakarta

Creswell, C. (2014). Research Design Pendekatan Kualitatif, Kuantitatif dan Mixed. Yogyakarta: Graha Ilmu

Husein, U. (2014). Metode Penelitian untuk Skripsi dan Tesis Bisnis Bisnis, Edisi-2, Cetakan Ke-13. Jakarta: Rajawali Pers 
Ikatan Akuntansi Indonesia. (2012). Standar Akuntansi Keuangan. Jakarta: Salemba Empat

Ikatan Akuntansi Indonesia. (2016). Standar Akuntansi Keuangan Entitas Mikro, Kecil dan Menengah. Jakarta: Dewan Standar Akuntansi Keuangan Ikatan Akuntansi Indonesia

Isnawan, G. (2012). Akuntansi Praktis untuk UMKM. Jakarta: Laskar Aksara

Mubiroh, S., Ruscitasari, Z. (2019). Implementasi SAK EMKM Dan Pengaruhnya Terhadap Penerimaan Kredit UMKM. Berkala Akuntansi dan Keuangan Indonesia, 4(2), 1-15

Munawir, S. (2010). Analisis Laporan Keuangan, Edisi Keempat, Cetakan Kelima Belas. Yogyakarta: Liberty

Ningtyas, J. D. A. (2017). Penyusunan Laporan Keuangan UMKM Berdasarkan Standar Akuntansi Keuangan Entitas Mikro, Kecil dan Menengah (SAK EMKM) (Studi Kasus pada Bintang Malam Pekalongan). Owner, 1(2), 11-17

Sugiyono, S. (2014). Meode Penelitian Kuantitatif Kualitatif dan R\&D. Bandung: Alfabeta

Suryana, S. (2001). Kewirausahaan. Jakarta: Salemba Empat

Tunggal, H. S. (2008). Undang-Undang Usaha Mikro Kecil dan Menengah. Jakarta: Harvarindo

Undang-Undang Republik Indonesia No. 20. (2008). Usaha Mikro, Kecil dan Menengah. https://www.ojk.go.id/sustainable-finance/id/peraturan/undangundang/Pages/Undang-Undang-Republik-Indonesia-Nomor-20-Tahun-2008-

Tentang-Usaha-Mikro,-Kecil,-dan-Menengah.aspx

Uno, M. O., Kalangi, L., \& Pusung, R. J. (2019). Analisis Penerapan Standar Akuntansi Keuangan Entitas Mikro, Kecil dan Menengah (SAK EMKM) pada Usaha Mikro, Kecil dan Menengah (Studi Kasus pada Rumah Karawo di Kota Gorontalo). Jurnal EMBA, 7(3), 3887-3898 